\title{
Motivators of impulsivity to smoke waterpipe tobacco among Nigerian youths: the moderating role of social media normalisation of waterpipe tobacco
}

\author{
Agatha Oluwafunmilayo Adu \\ Universiti Sains Malaysia \\ Nurzali Ismail ( $\boldsymbol{D}$ nurzali@usm.my ) \\ Universiti Sains Malaysia \\ Shuhaida Md Noor \\ Universiti Sains Malaysia
}

\section{Research Article}

Keywords: waterpipe tobacco smoking, impulsivity, social media, normalisation, youths, university, Nigeria

Posted Date: February 22nd, 2022

DOI: https://doi.org/10.21203/rs.3.rs-1310574/v1

License: @ (i) This work is licensed under a Creative Commons Attribution 4.0 International License. Read

Full License 


\section{Abstract}

Background: Impulsivity is a formidable cause of waterpipe tobacco smoking among the youths, however, it is less well studied among African youths. Using PRIME behavioural theory, this study aimed to develop a model that examines the motivators of impulsivity to smoke waterpipe tobacco in linkage to the moderating role of social media normalisation of waterpipe tobacco among youths in Nigeria.

Methods: Data were drawn from 695 youths who smoke waterpipe tobacco across six Nigerian universities in the south-west zone using the chain-referral sampling procedure. Descriptive analyses of the obtained data were carried out using the Statistical Package for Social Sciences (SPSS) version 25. The constructs in the developed model were validated through Partial Least Squares Structural Equation Modelling (PLS-SEM) in SmartPLS version 3.

Results: Among the Nigerian youths who smoke waterpipe tobacco, intention $(\beta=0.442, P<0.001)$ is the strongest motivator of impulsivity to smoke waterpipe tobacco as compared to positive evaluations $(\beta=0.302$, $P<0.001)$. Additionally, social media normalisation of waterpipe tobacco acts as a moderator that strengthens the relationship between intention and impulsivity $(\beta=0.287, P<0.01)$ as well as between positive evaluations and impulsivity $(\beta=0.186, P<0.01)$ among the youths.

Conclusion: Willingness greatly instigates the Nigerian youths' impulsivity to smoke waterpipe tobacco, and social media normalisation of waterpipe tobacco also considerably increases their impulsivity to smoke waterpipe tobacco. Youth-focused educative waterpipe tobacco cessation-oriented programmes that will utilise diverse constructive-based learning approaches like illustrative learning and counselling, are needed to enlighten and encourage the Nigerian youths on the importance of shunning the desirability to smoke waterpipe tobacco.

\section{Introduction}

Over the years, the use of tobacco has remained a worldwide hazardous issue causing a mortality rate of over 7 million annually [1]. Consumption of tobacco is often by various means such as cigarette, cigar, chewing, snuff, snus, waterpipe, amongst others [2]. Among these forms of tobacco use, waterpipe is perhaps the most dangerous as it is mostly assumed to be minimally harmful and addictive when compared to other methods of tobacco use, and so the level of waterpipe tobacco smoking (WTS) continue to rise especially among the youths [3]. In North America for instance, a $42 \%$ increase in youths' WTS has been reported in Canada [4] as well as a $2 \%$ increase among the youths in the USA [5]. Also in Asia, growing rate in WTS is noticeable among $26.6 \%$ of Iranian youths [6] and $23 \%$ of Palestinian youths [7]. In Africa, although related empirical data among the youths is scant [8], studies have shown a rapid growth in WTS among $26.1 \%$ of the youths in Rwanda [9], $36.4 \%$ in Uganda [10], and also $44 \%$ in Nigeria [11].

Contrary to the misperceptions indicating that the health detriments of waterpipe tobacco (WT) are merely slight, which have been contributing to the increase in its use among the youths [3], its health effects are notably more harmful compared to other methods of tobacco use [12]. Risk of respirational damage is higher among WT smokers as in addition to the smoke from the lit charcoal in the waterpipe, they also inhale greater amount of tobacco smoke due to the lengthy propensity of smoking sessions, often lasting up to an hour or 
more unlike cigarette smoking for instance that can be done within five minutes [13]. The unsanitary act of sharing waterpipe hose during smoking sessions is also related to the transmission of communicable diseases like tuberculosis and meningitis [14]. More recently is that the deadly Corona Virus Disease 2019 (COVID-19) which is elicited by a group of immensely transferrable viruses known as Severe Acute Respiratory Syndrome Coronavirus-2 (SARS-CoV-2) is also an associated disease of WTS [15]. A COVID-19 infected WT smoker can infect other persons as the exhalation of tobacco smoke is mingled with fluid from the salivary gland [16]. Worldwide, as of April 23, 2020, COVID-19 contracted cases were around 2,700,800 with more than 189,000 mortality rate, and there remains an upsurge [17]. In Nigeria, report as of September 22, 2021, shows that COVID-19 was responsible for 2,664 mortality rate [18]. Thus, the youths' unceasing impulsivity to smoke WT remains a public health concern that should be further comprehended.

Impulsivity is describable as an uncontrollable nudge to carry out an action, such that when it arises, there is a high possibility for the associated action to immediately take place, as such, impulsive tobacco smoking can become troublesome to control [19]. One major motivating factor of the youths' impulsivity to smoke WT is intention, also referred to as willingness. Supporting instance is a study in Canada that discovered an $18 \%$ propensity to smoke WT among youths who had the willingness to do so [20]. Positive evaluations, also known as positive beliefs or feelings, is another influential motivator of the youths' impulsivity to smoke WT. Of relevance is a study in Jordan revealing that the vulnerability to smoke WT among youths is strongly associated with such positive evaluations as the sweetness of its tobacco flavours like chocolate, strawberry, amongst others, as well as the ability to smoke it within a social gathering [21].

Furthermore, social media normalisation of waterpipe tobacco seems to have the ability to heighten the relationship between youths' related intention, positive evaluations, and impulsivity. Normalisation in the tobacco context symbolises the situation whereby many people in the society now consider an unhealthy behaviour like tobacco smoking as a normal and social behaviour rather than a harmful one that should be disposed of in the society [22]. As such, social media normalisation of WT is a concept that explains that the majority of the social media content related to WT in the format of text, pictures, videos, etc., frequently encourage rather than discourage its use [23]. That is, information pertaining to the use of waterpipe tobacco on social media like Twitter, Facebook, Instagram, etc., is more pro-smoking than anti-smoking [24]. This implies that the dawn of social media, which allows unrestrictive exposure to all manner of information, has made majority of the youths to become bombarded with a variety of information that are devoid of the harmful nature of WT [23], especially as the youths are the highest populace on social media [25].

Consequently, the research objective is to develop a model that investigates the relationship between intention, positive evaluations, and impulsivity while considering the moderating effect of social media normalisation in relation to WTS among the youths in Nigeria. To achieve this study's aim, we concentrate on the perspective of PRIME (plans, responses, impulses, motives, evaluations) behavioural theory which explains that actions that are unhealthy and addictive are heralded by an impulsiveness which is instigated by intention, positive evaluations, as well as outer environmental factors such as information from the media [26]. The salient contributions of this study are as follows: (a) In the African context, as empirical research on WT especially among youths is quite limited [8], this study contributes to emerging studies on youths WTS in an African country like Nigeria; (b) In the Nigerian context, as studies on WT are only just emerging with very minimal assessment among the youths $[11,27,28]$, this study responds to the vital need for empirical research on WTS 
among the Nigerian youths. Moreover, the study also responds to the call for future researchers to theoretically elucidate the Nigerian youths' tendency to smoke WT [29, 30]; (c) Based on suggestion that further research should employ newer and developing theories in the understanding of addictive behaviour [31], this study responds to this call by utilising a relatively new theory such as PRIME in the development of the research model; (d) As scholars have mostly so far employed PRIME theory in the assessment of tobacco smoking cessation [32,33], this study expands the understanding of PRIME by extending its relevance to examining the impulsivity to smoke tobacco as related to waterpipe.

\section{Theoretical Underpinning}

Our theoretical foundation is built upon the PRIME behavioural theory by Robert West describing plans, responses, impulses, motives, and evaluations as related to addictive behaviour [34]. Diverging from other behavioural theories i.e., theory of planned behaviour, theory of reasoned action, amongst others, that focuses on the nature of intention [31], PRIME focuses on the nature of impulsivity and inhibition [26]. The PRIME perspective explains that impulsivity is the drive behind an individual's susceptibility to an addictive behaviour while inhibition is the drive behind an individual's ability to refrain from an addictive behaviour [35]. Regarding impulsivity, an individual's prior intent (or plan) to act on an addictive behaviour, encouragement from outer environmental or personal motivators to act on the addictive behaviour, as well as positive evaluations (or beliefs) about such addictive behaviour can stimulate an irresistible response to act on such behaviour [36]. However, in the presence of inhibition, an individual's prior intent not to act on an addictive behaviour, discouragement from outer environmental or personal motivators on the addictive behaviour, as well as negative evaluations about such addictive behaviour can generate an ability to resist the desirable urge to act on such behaviour [37]. Thus, impulsivity is laced by irrationality while inhibition is laced by rationality [38].

A variety of existing studies have successfully shown the applicability of inhibition based on PRIME's perspective to effective tobacco smoking cessation efforts [33, 39-41]. Nevertheless, PRIME's relevance to the understanding of impulsivity as related to tobacco smoking is less well studied [31]. Considering that PRIME is a developing theory [42], empirical studies from not just the angle of inhibition, but also the angle of impulsivity are both of relevance in expounding its applicability to the understanding of an addictive behaviour like tobacco smoking. The present study formulates a predictive model which indicates that there is a positive link between impulsivity, intent (or plan), and positive evaluations (or beliefs) as suggested in existing studies on youths' WTS $[7,43]$. Also, based on prior evidences $[23,44]$, we include social media normalisation of WT as an outer environmental factor that can moderate the relationship between intention, positive evaluations, and impulsivity among the youths.

\section{Hypotheses development}

We developed hypotheses for the concepts of intention to smoke waterpipe tobacco, positive evaluations of waterpipe tobacco, and social media normalisation of waterpipe tobacco.

Intention to smoke waterpipe tobacco (ITSW). Intention refers to the willingness to carry out an action [45]. In the context of this study, intention refers to the willingness to smoke WT which can generate an impulsiveness or urge to smoke it. Studies have shown that the readiness to experiment with WT constitute the urge to smoke 
it among majority of the youths $[9,10,20,43,46]$. In Nigeria, willingness is also a key factor in the growing tendency to smoke WT among the youths, particularly those in the university [11]. As such, we assume that there is a positive connection between intention and impulsivity among the Nigerian youths who tend to smoke WT. Thus, we propose the following hypothesis:

H1. Intention to smoke waterpipe tobacco will be positively related to impulsivity among the Nigerian youths who have a tendency to smoke waterpipe tobacco.

Positive evaluations of waterpipe tobacco (PEOW). Positive evaluations entail the beliefs, feelings, or notions that depicts something in an advantageous manner [47]. In the context of waterpipe tobacco, positive notions that WT is merely trifling in terms of harm and addiction persists among many of the youths thereby instigating their continuous urge to smoke it [7]. Further stimulating the youths' tendency to smoke WT are such positive feelings as it being sociable, tasty due to flavours, entertaining, amongst others [48]. Positive feelings about WT also relates to the Nigerian context as many of the youths are known to mostly consider it as more of a fun activity [29]. Consequently, we propose that there is a positive association between positive evaluations and impulsivity among the Nigerian youths who tend to smoke WT and hypothesised that:

H2. Positive evaluations of waterpipe tobacco will be positively related to impulsivity among the Nigerian youths who have a tendency to smoke waterpipe tobacco.

Social media normalisation of waterpipe tobacco as a moderator (SMNW). Social media normalisation of waterpipe tobacco indicates the enormous depiction of WT on social media platforms like Facebook, Twitter, Instagram, YouTube, etc, as mostly a normal and acceptable behaviour rather than a highly detrimental one [49]. The illustration of WT on social media is quite bothersome as while harmful potential is often acknowledged in the social media messages related to other tobacco smoking methods like cigarette for instance [44], those associated with WT regularly describe it as more of a safer tobacco smoking alternative [23]. In fact, majority of the texts, pictures, videos, and other graphics related to WT on social media are reportedly representative of waterpipe as socially acceptable, fun, interesting, entertaining, enjoyable, attractive, amongst others $[50,51]$. Studies have shown that exposure to pro-smoking social media messages increases the youths' tendency to smoke tobacco $[52,53]$, especially among those who hold positive beliefs and are willing to experiment with tobacco [54]. Taken together, we therefore consider that the positive relationship between intention, positive evaluations, and impulsivity will be more intense among the youths with high exposure to pro-smoking social media messages that relate to WT. Consequently, we hypothesised that:

H3a. Social media normalisation of waterpipe tobacco will moderate the positive relationship between intention and impulsivity such that the tendency to smoke waterpipe tobacco will be stronger for the Nigerian youths with high exposure to pro-smoking social media messages relating to waterpipe tobacco.

H3b. Social media normalisation of waterpipe tobacco will moderate the positive relationship between positive evaluations and impulsivity such that the tendency to smoke waterpipe tobacco will be stronger for the Nigerian youths with high exposure to pro-smoking social media messages relating to waterpipe tobacco.

(Please insert Fig. 1 here) 


\section{Methodology}

\section{Research setting and design}

This study adopted the survey research design. Given that more of the Nigerian youths in the university consider WT as a normal and social activity [11], we surveyed Nigerian youths between ages 18-35 who: smoke WT, are social media users, and are current university students in a location like the south-west zone where many of the youths are increasingly prone to tobacco smoking [55].

Specifically, one university was purposively selected in each of the six states in the south-west zone of Nigeria namely: Ekiti State University Ado-Ekiti [EKSU] (Ekiti State); Lagos State University [LASU] (Lagos State); Federal University of Technology Akure [FUTA] (Ondo State); University of Ibadan [UI] (Oyo State); Obafemi Awolowo University lle-lfe [OAU] (Osun State); and Federal University of Agriculture Abeokuta [FUNAAB] (Ogun State) [56]. In terms of sample size, we employed the $G^{*}$ power method with effect size of 0.15 , alpha of 0.05 , and a power of 0.80 to get a minimum sample of 68 . However, since we are dealing with a heterogenous group [57], we increased our sample size to 660 . As such, 110 respondents were required for the survey in each of the selected universities. Nevertheless, for data collection purposes, based on the likelihood for missing data as well as youths who do not smoke WT, the required sample size $(n=110)$ per university was increased by $40 \%$ as recommended [58]. As an increase of 110 by $40 \%$ is 154 , we therefore surveyed 154 participants in each of the six selected universities rounding up to a total of 924 respondents.

The survey questionnaires were physically administered and the chain-referral non probability sampling procedure was utilised for the participants' recruitment [59]. To facilitate the field work, one student was recruited as a field assistant in each of the six universities and were extensively briefed on the study's criteria. To ensure that only WT smokers were recruited, tracking was done through the following affirmation in the questionnaire, "Never smoked waterpipe." Regarding social media usage, all the participants were required to affirm the specific type of social media they use in the questionnaire. Also, age category in the questionnaire was strictly within the margin of 18-35 years to ensure the recruitment of only the participants who are within the study's age requirement.

The data were collected between May 2021 to August 2021. To keep safe from the COVID-19, all field assistants were required to use face masks during interactions with the respondents, maintain social distance, and also take along at least one bottle of hand sanitiser in order that they and the participants can disinfect their hands. Additionally, whenever they met with participants, field assistants were required to take along few new packs of face masks for the participants use. The hand sanitisers and face masks were provided by the researchers. In total, 695 (response rate 75.2\%) questionnaires were useable for analyses. A sample size of 695 will generate a power of over $95 \%$, as such, our sample is enough to generate confident outcomes [60]. Table 1 displays the respondents' characteristics.

\section{Constructs and measures}

We had four constructs, two independent variables (intention to smoke WT, positive evaluations of WT), one dependent variable (impulsivity to smoke WT), and one moderating variable (social media normalisation of WT). All items were rated on a seven-point Likert scale ranging from " $1=$ strongly disagree to 7 = strongly agree," and all were reflective measures. The four items for intention were adapted from one study [61]. Also, 
the nine items for impulsivity were adapted from a prior study [62]. However, the items for positive evaluations of WT and social media normalisation of WT were developed using the construct development process from one study [63]. First, we interviewed six youths (3 males, 3 females) who smoke WT and are social media users. The youths were recruited for the interview through one of the authors contact who works in a Nigerian based university and anonymity was requested and has been guaranteed.

For the construct of positive evaluations of WT, the interviewees were asked to describe their preference for WT as opposed to other tobacco smoking methods. Only one of the participants (female) expressed that she enjoys smoking WT even though she feels it is harmful to health. All other participants considered WT as less harmful and addictive, and generally had favourable opinion on it. For the construct of social media normalisation of WT, the interviewees were asked to confirm whether they had ever come across social media messages that promote the use of WT and to give their opinion on the influence of such messages based on their experiences. One of the interviewees (female) mentioned coming across such messages only a few times. The other five respondents affirmed that they regularly see such messages. Of the five, four ( 3 males, 1 female) expressed a likeness for the usually colourful and interesting nature of social media WT messages to the point that they often click the like button, post a comment, or even share with friends.

Secondly, based on the above interviews as well as existing studies as follows: positive evaluations of WT [21, 64]; social media normalisation of WT [54, 65], we generated eight initial items for both constructs. Thirdly, we then consulted five experts who are conversant with youth behavioural studies and are all social media users. At this stage, the items for both positive evaluations of WT and social media normalisation of WT became nine and six respectively.

Finally, to further minimise ambiguity in the survey, we conducted a preliminary study with 70 youth respondents in a Nigerian based university. Questionnaires were physically administered using the chainreferral procedure. Of the 70 questionnaires distributed, 53 (response rate $75.7 \%$ ) were useable. The final questionnaire is presented in Table 2.

(Please insert Table 1 here)

\section{Data analyses method}

Statistical Package for Social Sciences (SPSS) version 25 was relevant in the descriptive segment for frequencies, percentages, mean, and standard deviation of the participants' characteristics and variables distribution. We also assessed common method bias (CMB) in SPSS through Harman's single factor test and a single factor was less than $50 \%$ signifying that no single factor explained the majority of the variance in our data. Partial least squares structural equation modelling (PLS-SEM) was applied in SmartPLS version 3 to assess the significance of the model constructs through measurement model, structural model, and moderator analyses [66]. We also checked for collinearity in SmartPLS by examining the variance inflation factor (VIF) of the constructs and none exceeded the boundary of 5 (see Table 3) [57]. Consequently, CMB and collinearity posed no problem in our study [67].

\section{Results}




\section{Measurement model}

Except for IMP8 which had a loading of 0.519 , the study's indicator loadings, composite reliability, and Cronbach's alpha values were above 0.70 [68]. It is recommended that an indicator loading $>0.40$ but $<0.70$ should be retained if the Average Variance Extracted (AVE) is $>0.50$ [66], consequently, IMP8 was retained since its related AVE exceeded 0.50 (see Table 2). For discriminant validity, all values were below 0.90 as recommended [69] (see Table 4).

\section{Structural model}

We tested the significance of the study's model by using a 5000 bootstrapping procedure at $5 \%$ significance level (one-tailed) [68]. Table 4 and Figure 2 shows that intention $(\beta=0.442, P<0.001)$ and positive evaluations $(\beta=0.302, P<0.001)$ positively predicted impulsivity in relation to WT. Therefore, $\mathrm{H} 1$ and $\mathrm{H} 2$ were supported in our study. In addition, gender had no significant effect on impulsivity to smoke WT, but age $(\beta=0.054, P<0.05)$ and year of study $(\beta=0.056, P<0.05)$ were significant. Effect sizes for $H 1\left(f^{2}=0.194\right)$ and $H 2\left(f^{2}=0.091\right)$ were acceptable based on the rule of thumb of $0.02,0.15$, and 0.35 as small, medium, and large respectively [70]. Also, the predictive relevance $\left(\mathrm{Q}^{2}\right)$ of our model is $0.312>0$, signifying that the model has excellent predictive relevance [60]. Finally, our model explains $46.8 \%$ of the variance $\left(R^{2}\right)$ in the youths' impulsivity to smoke WT. A variance that is equal to or $>0.10$ is considered to be adequate [71]. As such, the predictors in our model substantially explained the dependent variable.

\section{Testing the moderator}

Results showed that social media normalisation of WT moderates the relationship between intention and impulsivity $(\beta=0.287, P<0.01)$ as well as between positive evaluations and impulsivity $(\beta=0.186, P<0.01)$. Figure 3 and Figure 4 further clarifies that the two moderating effects are significant. Furthermore, effect size

$\left(f^{2}\right)$ in moderation analysis is $0.025,0.01$, and 0.005 for large, medium, and small respectively [72], thus, the $\mathrm{f}^{2}$ values of the moderating effects, $\mathrm{H} 3 \mathrm{a}(0.136)$ and $\mathrm{H} 3 \mathrm{~b}(0.112)$ indicates large moderation effects (see Table 4).

\section{(Please insert Table 2 here)}

\section{(Please insert Figure 2 here)}

\section{Discussion Of Findings}

For the main effects, our findings show that both intention and positive evaluations predicted impulsivity in relation to WTS among the youths. As such, willingness and positive feelings trigger youths' impulsiveness to smoke WT. Of both constructs, intention had more effect on impulsivity to smoke WT compared to positive evaluations. This is consistent with previous research which positioned intention as a formidable predictor of the youths' likelihood to smoke WT [73]. Therefore, willingness creates an acceptability that strongly contributes to the tendency to smoke WT among the youths. In addition, age and year of study predicted the youths' impulsivity to smoke WT. Specifically, youths who are below the age of 30 are more likely to impulsively smoke WT. This aligns with prior research which found that youths above 'age 20' but below 'age 
30 ' often impulsively smoke WT [9]. On the other hand, we found that the youths who are at postgraduate level are more likely to impulsively smoke WT. This contradicts prior research showing that impulsivity and addictiveness in relation to WT is prevalent among the youths who are undergraduate students [74]. This contradiction may be tilted towards the higher length of time (between 6 to 10 years) that more of the youths at the postgraduate level in this study had been smoking WT. The lengthier the period of impulsive tobacco smoking, the more challenging it becomes to control [38]. As WT contains high levels of nicotine, many of the youths who impulsively smoke it over a longer period of time gradually become addicted without being aware of their addiction [75].

In terms of the moderation effects, findings (see Fig. 3) show that the relationship between intention and impulsivity to smoke WT is stronger among the youths with high exposure to pro-smoking social media messages related to WT. These findings indicate that social media messages that encourages the use of WT has the ability to increase the youths' desirability to smoke it. This result is similar to prior research which found a positive link between social media pro-smoking messages and tobacco smoking among the youths [53]. Furthermore, as displayed in Fig. 4, we found that social media normalisation of WT moderates the relationship between positive evaluations and impulsivity to smoke WT among the youths. In other words, positive beliefs, feelings, or notions about WT is stronger among the youths with high exposure to social media pro-smoking messages related to WT. This outcome is comparable to previous findings showing that there is a significant connection between social media and positive expressions of tobacco smoking among the youths [54].

(Please insert Fig. 3 here)

(Please insert Fig. 4 here)

\section{Conclusion}

Our study demonstrated that intention and positive evaluations are factors instigating the impulsivity to smoke WT among the Nigerian youths. Greater effect of intention was found on the youths' impulsivity to smoke WT as compared to positive evaluations. Also, social media normalisation of WT increases the effect of intention and positive evaluations on the youths' impulsivity to smoke WT. Additionally, age and year of study influences the youths' impulsivity to smoke WT. These outcomes have some theoretical and practical implications as demonstrated in the following sections.

\section{Theoretical And Empirical Implications}

Our study contributes to the advancement of the PRIME theory. Previous studies often utilised PRIME from its perspective of inhibition by applying it in the assessment of tobacco smoking cessation [33, 39-41]. Thus, by expounding its perspective of disinhibition as related to impulsivity to smoke WT, this study has responded to the call to show the applicability of a developing theory like PRIME to addictive behaviour [31]. Moreover, this study has also responded to the recommendation for researchers to theoretically explicate the Nigerian youths tendency to smoke WT [30]. In addition, we developed items for the measurement of two constructs (positive evaluations of WT, social media normalisation of WT) which future researchers may find useful. 


\section{Practical Implications}

We posit that although governmental policies that restrict WTS in the country may discourage its use among the youths, however, to a large extent, enactment of policies is not enough to minimise the youths' impulsivity to smoke WT. Thus, we suggest that the Nigerian government should collaborate with other stakeholders such as the university council, conventional media professionals, and public health professionals, to introduce and implement youth-focused educative WT cessation programmes that will utilise diverse constructive-based learning approaches like counselling, cooperative learning, illustrative learning, amongst others, which can help the youths to feel a sense of enlightenment and encouragement, rather than the forceful expectancies divulged through policies. We also recommend that digital-based platforms should be increasingly incorporated in WT related cessation efforts as this may help to neutralise the influential role of social media normalisation of WT among the Nigerian youths.

\section{Limitations And Suggestion For Further Studies}

Even though this study has broadened our understanding of youths' impulsivity as related to WT in an under explored region like Nigeria, the study has some limitations that should be mentioned. The study focused on the Nigerian youths who are current university students in the south-west zone. This was due to WTS being on rapid rise among the youths in the university [11], and because it is still difficult to locate current WT smokers in Nigeria [76], we specifically surveyed in the south-west zone where the use of tobacco is reportedly popular among the youths [55]. Nonetheless, future researchers should recruit from other geopolitical zones like the north-central, south-south, etc., and should extend to the Nigerian youths who are not current students in the university. Also, future researchers could assess youths' impulsivity related to WT using other measures i.e., peer influence, family influence, etc., either as direct effects or mediators.

\section{Abbreviations}

WT: Waterpipe Tobacco; WTS: Waterpipe Tobacco Smoking; COVID-19: Corona Virus Disease 2019; ITSW: Intention to Smoke Waterpipe; PEOW: Positive Evaluations of Waterpipe; SMNW: Social Media Normalisation of Waterpipe; IMP: Impulsivity to Smoke Waterpipe; PRIME: Plans, Responses, Impulses, Motives, Evaluations; PLS-SEM: Partial Least Squares Structural Equation Modelling; SPSS: Statistical Package for Social Sciences; CMB: Common Method Bias; VIF: Variance Inflation Factor; AVE: Average Variance Extracted; CA: Cronbach Alpha; CR: Composite Reliability; M: Mean; SD: Standard Deviation; EKSU: Ekiti State University; LASU: Lagos State University; FUTA: Federal University of Technology Akure; UI: University of Ibadan; OAU: Obafemi Awolowo University; FUNAAB: Federal University of Agriculture Abeokuta.

\section{Declarations}

\section{Acknowledgements}

We thank the expert panel for their valuable feedback which enhanced the quality of the research instrument, and the field assistants for their help in collecting the data. We also thank all the study respondents for their participation. 


\section{Authors' contributions}

Adu Agatha wrote the main text including analysis. Nurzali Ismail and Shuhaida Md Noor assisted in preparing the framework, instrument and reviewed the text.

\section{Funding}

This research was funded by the Fundamental Research Grant, Ministry of Higher Education Malaysia (203.PCOMM.6711748).

\section{Availability of data and materials}

Datasets are available from the corresponding author on reasonable request.

\section{Declarations}

This study has received ethical approval from the Human Research Ethics Committee, Universiti Sains Malaysia (USM). Prior to their participation, the participants have given informed written consent to participate in this research. They also consent for the findings of the research to be published.

\section{Ethics approval and consent to participate}

Ethical approval was obtained from the Human Research Ethics Committee, Universiti Sains Malaysia (protocol USM/JEPeM/21020181). The research complied with the declaration of Helsinki. All the participants gave an informed written consent and were well informed on the study's purpose as well as their confidentiality and rights to withdraw at any point from the survey.

\section{Consent for publication}

The participants were well informed on the publications that will be published based on this research and have given informed written consent.

\section{Competing interests}

The authors declare that they have no competing interests.

\section{Author details}

${ }^{1}$ School of Communication, Universiti Sains Malaysia, Penang, Malaysia.

\section{References}

1. Al Oweini D, Jawad M, Akl EA. The association of waterpipe tobacco smoking with later initiation of cigarette smoking: a systematic review and meta-analysis exploring the gateway theory. Tob. Control [Internet] 2019;29:tobaccocontrol-2018-054870. Available from: https://tobaccocontrol.bmj.com/lookup/doi/10.1136/tobaccocontrol-2018-054870 
2. Watkins SL, Glantz SA, Chaffee BW. Association of Noncigarette Tobacco Product Use With Future Cigarette Smoking Among Youth in the Population Assessment of Tobacco and Health (PATH) Study, 2013-2015. JAMA Pediatr. [Internet] 2018;172:181. Available from:

http://archpedi.jamanetwork.com/article.aspx?doi=10.1001/jamapediatrics.2017.4173

3. Gathuru IM, Tarter RE, Klein-Fedyshin M. Review of hookah tobacco smoking among college students: policy implications and research recommendations. Am. J. Drug Alcohol Abuse [Internet] 2015;41:272-80. Available from: http://www.tandfonline.com/doi/full/10.3109/00952990.2015.1043738

4. Abdullah P, Costanian C, Khanlou N, Tamim H. Prevalence and characteristics of water-pipe smoking in Canada: results from the Canadian Tobacco Use Monitoring Survey. Public Health [Internet] 2017;148:102-8. Available from: http://dx.doi.org/10.1016/j.puhe.2017.03.007

5. Soulakova JN, Pham T, Owens VL, Crockett LJ. Prevalence and factors associated with use of hookah tobacco among young adults in the U.S. Addict. Behav. [Internet] 2018;85:21-5. Available from: https://doi.org/10.1016/j.addbeh.2018.05.007

6. Bashirian S, Barati M, Abasi H, Sharma M, Karami M. The role of sociodemographic factors associated with waterpipe smoking among male adolescents in western Iran: A cross-sectional study. Tob. Induc. Dis. [Internet] 2018;16:1-8. Available from: http://www.journalssystem.com/tid/The-role-of-sociodemographic-factors-associated-with-water-pipe-smoking-among-male,91601,0,2.html

7. Nazzal Z, Al-Halaweh MA, Musmar S. Social Norms and Perception of Waterpipe Smoking among Palestinian University Students. Palest. Med. Pharm. J. 2020;5:25-9.

8. WHO Study Group on Tobacco PR. Advisory note: waterpipe tobacco smoking health effects, research needs and recommended actions by regulators [Internet]. 2015. Available from: http://apps.who.int/iris/bitstream/10665/161991/1/9789241508469_eng.pdf?ua=1

9. Omotehinwa OJ, Japheths O, Damascene IJ, Habtu M. Shisha use among students in a private university in Kigali city, Rwanda: prevalence and associated factors. BMC Public Health [Internet] 2018;18:713. Available from: https://bmcpublichealth.biomedcentral.com/articles/10.1186/s12889-018-5596-1

10. Aanyu C, Kadobera D, Apolot RR, Kisakye AN, Nsubuga P, Bazeyo W, et al. Prevalence, knowledge and practices of shisha smoking among youth in Kampala City, Uganda. Pan Afr. Med. J. [Internet] 2019;32:110. Available from: http://www.panafrican-med-journal.com/content/article/32/61/full/

11. Abraham E, Egbe C, Ayo-Yusuf O. News media coverage of shisha in Nigeria from 2014 to 2018 . Tob. Induc. Dis. [Internet] 2019;17:1-10. Available from: http://www.journalssystem.com/tid/News-mediacoverage-of-shisha-in-Nigeria-from-2014-to-2018,106139,0,2.html

12. Akl EA, Ward KD, Bteddini D, Khaliel R, Alexander AC, Lotfi T, et al. The allure of the waterpipe: a narrative review of factors affecting the epidemic rise in waterpipe smoking among young persons globally. Tob. Control [Internet] 2015;24:i13-21. Available from:

https://tobaccocontrol.bmj.com/lookup/doi/10.1136/tobaccocontrol-2014-051906

13. Wong L, Alias H, Aghamohammadi N, Aghazadeh S, Hoe V. Shisha Smoking Practices, Use Reasons, Attitudes, Health Effects and Intentions to Quit among Shisha Smokers in Malaysia. Int. J. Environ. Res. Public Health [Internet] 2016;13:726. Available from: http://www.mdpi.com/1660-4601/13/7/726

14. Shekhar S, Hannah-Shmouni F. Hookah smoking and COVID-19: call for action. Can. Med. Assoc. J. [Internet] 2020;192:E462-E462. Available from: http://www.cmaj.ca/lookup/doi/10.1503/cmaj.75332 
15. Yang Y, Lindblom E, Salloum R, Ward K. Perceived health risks associated with the use of tobacco and nicotine products during the COVID-19 pandemic. Tob. Induc. Dis. [Internet] 2021;19:1-8. Available from: http://www.tobaccoinduceddiseases.org/Perceived-health-risks-associated-with-the-use-of-tobacco-andnnicotine-products, $136040,0,2 . \mathrm{html}$

16. Ahmed N, Maqsood A, Abduljabbar T, Vohra F. Tobacco Smoking a Potential Risk Factor in Transmission of COVID-19 Infection. Pakistan J. Med. Sci. [Internet] 2020;36:S104-7. Available from: http://www.pjms.org.pk/index.php/pjms/article/view/2739

17. Sugiyo D, Limato R, Handari SD. Tobacco Use and the Risk of Suffering from COVID-19. Open Access Maced. J. Med. Sci. [Internet] 2021;9:111-7. Available from: https://oamjms.eu/index.php/mjms/article/view/5757

18. Nigeria Centre for Disease Control N. Update on COVID-19 in Nigeria [Internet]. 2021;Available from: https://covid19.ncdc.gov.ng/

19. Dawe S, Gullo MJ, Loxton NJ. Reward drive and rash impulsiveness as dimensions of impulsivity: Implications for substance misuse. Addict. Behav. [Internet] 2004;29:1389-405. Available from: https://linkinghub.elsevier.com/retrieve/pii/S0306460304002187

20. Minaker LM, Shuh A, Burkhalter RJ, Manske SR. Hookah use prevalence, predictors, and perceptions among Canadian youth: findings from the 2012/2013 Youth Smoking Survey. Cancer Causes Control [Internet] 2015;26:831-8. Available from: http://dx.doi.org/10.1007/s10552-015-0556-x

21. Eshah NF, Froelicher ES. Knowledge, attitudes, beliefs and patterns of waterpipe use among Jordanian adults who exclusively smoke waterpipes. Eur. J. Cardiovasc. Nurs. [Internet] 2018;17:85-92. Available from: https://academic.oup.com/eurjcn/article/17/1/85-92/5925014

22. Asbridge M, Valleriani J, Kwok J, Erickson PG. Normalization and denormalization in different legal contexts: Comparing cannabis and tobacco. Drugs Educ. Prev. Policy [Internet] 2016;23:212-23. Available from: http://www.tandfonline.com/doi/full/10.3109/09687637.2015.1118442

23. Krauss MJ, Sowles SJ, Moreno M, Zewdie K, Grucza RA, Bierut LJ, et al. Hookah-Related Twitter Chatter: A Content Analysis. Prev. Chronic Dis. [Internet] 2015;12:150140. Available from: http://www.cdc.gov/pcd/issues/2015/15_0140.htm

24. Allem J-P, Chu K-H, Cruz TB, Unger JB. Waterpipe Promotion and Use on Instagram: \#Hookah. Nicotine Tob. Res. [Internet] 2017;19:ntw329. Available from: https://academic.oup.com/ntr/articlelookup/doi/10.1093/ntr/ntw329

25. Greenhow C, Chapman A, Marich H, Askari E. Social Media and Social Networks [Internet]. In: Peppler K, editor. The SAGE Encyclopedia of Out-of-School Learning. 2455 Teller Road, Thousand Oaks, California 91320: SAGE Publications, Inc.; 2017. Available from: http://sk.sagepub.com/reference/the-sageencyclopedia-of-out-of-school-learning/i8160.xml

26. West R, Brown J. Theory of Addiction [Internet]. Second. Chichester, UK: John Wiley \& Sons, Ltd; 2013. Available from: http://doi.wiley.com/10.1002/9781118484890

27. Jones GSA, Onyezere JO. Knowledge of shisha-aided flavoured tobacco smoking, health-risk in public universities in Rivers State. Int. J. Progress. Sci. Technol. 2020;24:202-9.

28. Kanmodi K, Fagbule OF, Aladelusi T, Kanmodi KK, Fagbule OF, Aladelusi TO, et al. Prevalence of shisha (waterpipe) smoking and awareness of head and neck cancer among Nigerian secondary school 
students: A preliminary survey Missed Diagnosis of Isolated Bilateral Transverse Facial Cleft: A Case Report View project Orofacial Infections V. Int Public Heal. J [Internet] 2018;10:209-14. Available from: https://www.researchgate.net/publication/323258643

29. Osibogun O, Odukoya O, Odusolu Y, Osibogun A. Knowledge and risk perception of E-Cigarettes and hookah amongst youths in Lagos State, Nigeria: and exploratory study. Niger. Postgrad. Med. J. 2020;27:384-90.

30. Lasebikan VO, Ola BA, Lasebikan TO. Shisha smoking in selected nightclubs in Nigeria. Pan Afr. Med. J. [Internet] 2019;33:1-11. Available from: http://www.panafrican-medjournal.com/content/article/33/136/full/

31. Sniehotta FF, Presseau J, Araújo-Soares V. Time to retire the theory of planned behaviour. Health Psychol. Rev. [Internet] 2014;8:1-7. Available from: http://dx.doi.org/10.1080/17437199.2013.869710

32. Troelstra SA, Kunst AE, Harting J. "Like you are fooling yourself": how the "Stoptober" temporary abstinence campaign supports Dutch smokers attempting to quit. BMC Public Health [Internet] 2019;19:522. Available from: https://bmcpublichealth.biomedcentral.com/articles/10.1186/s12889-0196833-y

33. Ubhi HK, Michie S, Kotz D, Wong WC, West R. A Mobile App to Aid Smoking Cessation: Preliminary Evaluation of SmokeFree28. J. Med. Internet Res. [Internet] 2015;17:e17. Available from: http://www.jmir.org/2015/1/e17/

34. West R. PRIME Theory of Motivation and its application to addiction [Internet]. 2006 [cited 2019 Nov 4];142. Available from: https://www.addictionssa.org/images/uploads/WestR_PRIME_Theory_Of_Motivation_Nov_2006.pdf

35. West R, Michie S. UBC briefing 9: a brief description of the PRIME theory of human motivation [Internet]. Unlocking Behav. Chang.2019 [cited 2020 Jan 15];1. Available from: https://www.unlockingbehaviourchange.com/pdfs/5c766c3b6c2a0550594975.pdf

36. Uppal N, Shahab L, Britton J, Ratschen E. The forgotten smoker: a qualitative study of attitudes towards smoking, quitting, and tobacco control policies among continuing smokers. BMC Public Health [Internet] 2013;13:432. Available from: http://bmcpublichealth.biomedcentral.com/articles/10.1186/1471-2458-13432

37. Michie S, Brown J, Geraghty AWA, Miller S, Yardley L, Gardner B, et al. Development of StopAdvisor. Transl. Behav. Med. [Internet] 2012;2:263-75. Available from: https://academic.oup.com/tbm/article/2/3/263$275 / 4562904$

38. Fidler JA, West R. Enjoyment of smoking and urges to smoke as predictors of attempts and success of attempts to stop smoking: A longitudinal study. Drug Alcohol Depend. [Internet] 2011;115:30-4. Available from: http://dx.doi.org/10.1016/j.drugalcdep.2010.10.009

39. Brown J, Kotz D, Michie S, Stapleton J, Walmsley M, West R. How effective and cost-effective was the national mass media smoking cessation campaign 'Stoptober'? Drug Alcohol Depend. [Internet] 2014;135:52-8. Available from: http://dx.doi.org/10.1016/j.drugalcdep.2013.11.003

40. McEwen A, West R. The PRIME approach to giving up smoking. Pract. Nurs. [Internet] 2010;21:145-53. Available from: http://www.magonlinelibrary.com/doi/10.12968/pnur.2010.21.3.46936 
41. Tombor I, Vangeli E, West R, Shahab L. Progression towards smoking cessation: Qualitative analysis of successful, unsuccessful, and never quitters. J. Subst. Use [Internet] 2018;23:214-22. Available from: https://doi.org/10.1080/14659891.2017.1378746

42. Ahmad M, Ibrahim M, Ab Rahman A, Musa K, Mohd Zin F, Mohd Zain R, et al. Development and Validation of Positive Smoker Identity Questionnaire (PSmoQi): A New Instrument for Smoking Cessation Correlates. Int. J. Environ. Res. Public Health [Internet] 2019;16:351. Available from: http://www.mdpi.com/16604601/16/3/351

43. Schröder C, Chaaya M, Saab D, Mahfoud Z. The determinants of intention to smoke waterpipe among adolescents in Lebanon: a national household survey. J. Public Health (Bangkok). [Internet] 2016;38:8491. Available from: https://academic.oup.com/jpubhealth/article-lookup/doi/10.1093/pubmed/fdv004

44. Carroll M V., Shensa A, Primack BA. A comparison of cigarette- and hookah-related videos on YouTube. Tob. Control [Internet] 2013;22:319-23. Available from:

http://tobaccocontrol.bmj.com/lookup/doi/10.1136/tobaccocontrol-2011-050253

45. McMillan B, Higgins AR, Conner M. Using an extended theory of planned behaviour to understand smoking amongst schoolchildren. Addict. Res. Theory [Internet] 2005;13:293-306. Available from: http://www.tandfonline.com/doi/full/10.1080/16066350500053679

46. Reveles CC, Segri NJ, Botelho C. Factors associated with hookah use initiation among adolescents. J. Pediatr. (Rio. J). [Internet] 2013;89:583-7. Available from: http://dx.doi.org/10.1016/j.jped.2013.08.001

47. Lee J, Johnson C, Rice J, Warren CW, Chen T. Smoking Beliefs and Behavior Among Youth in South Korea, Taiwan, and Thailand. Int. J. Behav. Med. [Internet] 2013;20:319-26. Available from: http://link.springer.com/10.1007/s12529-012-9236-3

48. Alqahtani MM, Goodfellow LT, Zimmerman RD, Zavorsky GS. Waterpipe Smoking in Health-Care Students: Prevalence, Knowledge, Attitudes, and Motives. Respir. Care [Internet] 2019;64:321-7. Available from: http://rc.rcjournal.com/lookup/doi/10.4187/respcare.06263

49. Grant A, O’Mahoney H. Portrayal of waterpipe (shisha, hookah, nargile) smoking on Twitter: a qualitative exploration. Public Health [Internet] 2016;140:128-35. Available from:

http://dx.doi.org/10.1016/j.puhe.2016.07.007

50. Guidry J, Haddad L, Jin Y, Zhang Y. \#Hookah, \#Shisha, \#Narghile: the Portrayal of \#Waterpipe Smoking on Instagram. J. Healthc. Commun. [Internet] 2017;02:1-7. Available from: http://healthcarecommunications.imedpub.com/hookah-shisha-narghile-the-portrayal-of-waterpipe-smoking-oninstagram.php?aid=19398

51. Primack BA, Carroll M V., Shensa A, Davis W, Levine MD. Sex Differences in Hookah-Related Images Posted on Tumblr: A Content Analysis. J. Health Commun. [Internet] 2016;21:366-75. Available from: https://www.tandfonline.com/doi/full/10.1080/10810730.2015.1095814

52. Depue JB, Southwell BG, Betzner AE, Walsh BM. Encoded Exposure to Tobacco Use in Social Media Predicts Subsequent Smoking Behavior. Am. J. Heal. Promot. [Internet] 2015;29:259-61. Available from: http://journals.sagepub.com/doi/10.4278/ajhp.130214-ARB-69

53. Zhu Y. Pro-smoking information scanning using social media predicts young adults' smoking behavior. Comput. Human Behav. [Internet] 2017;77:19-24. Available from: https://doi.org/10.1016/j.chb.2017.08.004 
54. Yoo W, Yang J, Cho E. How social media influence college students' smoking attitudes and intentions. Comput. Human Behav. [Internet] 2016;64:173-82. Available from:

https://linkinghub.elsevier.com/retrieve/pii/S0747563216304897

55. Oyewole BK, Animasahun VJ, Chapman HJ. Tobacco use in Nigerian youth: A systematic review. PLoS One [Internet] 2018;13:e0196362. Available from: https://dx.plos.org/10.1371/journal.pone.0196362

56. National Universities Commission N. Nigerian universities [Internet]. 2020 [cited 2020 Mar 12];Available from: https://www.nuc.edu.ng/

57. Hair JF, Risher JJ, Sarstedt M, Ringle CM. When to use and how to report the results of PLS-SEM. Eur. Bus. Rev. [Internet] 2019;31:2-24. Available from:

https://www.emerald.com/insight/content/doi/10.1108/EBR-11-2018-0203/full/html

58. Bartlett II JE, Kotrlik JW, Higgins CC. Determining appropriate sample size in survey research. Inf. Technol. Learn. Perform. J. [Internet] 2001;19:43-50. Available from: https://www.opalco.com/wpcontent/uploads/2014/10/Reading-Sample-Size1.pdf

59. Heckathorn DD. Respondent-Driven Sampling II: Deriving Valid Population Estimates from Chain-Referral Samples of Hidden Populations. Soc. Probl. [Internet] 2002;49:11-34. Available from: https://academic.oup.com/socpro/article-lookup/doi/10.1525/sp.2002.49.1.11

60. Sarstedt M, Ringle CM, Hair JF. Partial Least Squares Structural Equation Modeling [Internet]. In: Handbook of Market Research. Cham: Springer International Publishing; 2021. page 1-47.Available from: https://link.springer.com/10.1007/978-3-319-05542-8_15-2

61. Baker MJ, Churchill GA. The Impact of Physically Attractive Models on Advertising Evaluations. J. Mark. Res. [Internet] 1977;14:538-55. Available from:

http://journals.sagepub.com/doi/10.1177/002224377701400411

62. Rook DW, Fisher RJ. Normative Influences on Impulsive Buying Behavior. J. Consum. Res. [Internet] 1995;22:305. Available from: https://academic.oup.com/jcr/article-lookup/doi/10.1086/209452

63. Moore GC, Benbasat I. Development of an instrument to measure the perceptions of adopting an information technology innovation. Inf. Syst. Res. [Internet] 1991;2:192-222. Available from: http://pubsonline.informs.org/doi/abs/10.1287/isre.2.3.192

64. Barnett TE, Shensa A, Kim KH, Cook RL, Nuzzo E, Primack BA. The predictive utility of attitudes toward hookah tobacco smoking. Am. J. Health Behav. [Internet] 2013;37:433-9. Available from:

http://openurl.ingenta.com/content/xref?genre=article\&issn=1087-

$3244 \&$ volume $=37 \&$ issue $=4 \&$ spage $=433$

65. Monismith SW, Shute RE, St. Pierre RW, Alles WF. Opinions of Seventh to Twelfth Graders regarding the Effectiveness of Pro- and Anti-Smoking Messages. J. Drug Educ. [Internet] 1981;11:213-25. Available from: http://journals.sagepub.com/doi/10.2190/65H3-ACEK-61LG-K7E5

66. Hair Jr JF, Hult GT, Ringle CM, Sarstedt M. A primer on partial least squares structural equation modeling (PLS-SEM). SAGE Publications, Inc.; 2017.

67. Nitzl C, Roldan JL, Cepeda G. Mediation analysis in partial least squares path modeling. Ind. Manag. Data Syst. [Internet] 2016;116:1849-64. Available from:

https://www.emerald.com/insight/content/doi/10.1108/IMDS-07-2015-0302/full/html 
68. Sarstedt M, Ringle CM, Hair JF. Partial Least Squares Structural Equation Modeling [Internet]. In: Handbook of Market Research. Cham: Springer International Publishing; 2017. page 1-40.Available from: http://link.springer.com/10.1007/978-3-319-05542-8_15-1

69. Henseler J, Ringle CM, Sarstedt M. A new criterion for assessing discriminant validity in variance-based structural equation modeling. J. Acad. Mark. Sci. [Internet] 2015;43:115-35. Available from: http://link.springer.com/10.1007/s11747-014-0403-8

70. Cohen J. Statistical power analysis for the behavioural sciences. 2nd ed. Lawrence Erlbaum Associates Publishers; 1988.

71. Falk RF, Miller NB. A Primer for Soft Modeling [Internet]. 1992. Available from: http://books.google.com/books/about/A_Primer_for_Soft_Modeling.html?id=3CFrQgAACAAJ

72. Kenny DA. Moderation [Internet]. 2016 [cited 2021 Sep 26];Available from: http://davidakenny.net/cm/moderation.htm

73. Noonan D, Kulbok P, Yan G. Intention to Smoke Tobacco Using a Waterpipe Among Students in a Southeastern U.S. College. Public Health Nurs. [Internet] 2011;28:494-502. Available from: https://onlinelibrary.wiley.com/doi/10.1111/j.1525-1446.2011.00945.x

74. Salloum RG, Lee J, Mostafa A, Abu-Rmeileh NME, Hamadeh RR, Darawad MW, et al. Waterpipe Tobacco Smoking among University Students in Three Eastern Mediterranean Countries: Patterns, Place, and Price. Subst. Use Misuse [Internet] 2019;54:2275-83. Available from: https://doi.org/10.1080/10826084.2019.1645177

75. Bahelah R, Ward KD, Ben Taleb Z, Difranza JR, Eissenberg T, Jaber R, et al. Determinants of progression of nicotine dependence symptoms in adolescent waterpipe smokers. Tob. Control 2019;28:254-60.

76. Kanmodi KK, Mohammed FA, Nwafor NJ, Fagbule OF, Adesina MA, Aliyu BM, et al. Poor Knowledge of the Harmful Effects of Shisha Among Shisha Smokers: Findings from a Preliminary Survey in Northwest Nigeria. Med. Univ. 2019;2:49-56.

\section{Tables}

Table 1 Participants' profile 


\begin{tabular}{|c|c|c|}
\hline Characteristics & Frequency & Percentage (\%) \\
\hline \multicolumn{3}{|l|}{ Gender } \\
\hline Male & 325 & 46.8 \\
\hline Female & 370 & 53.2 \\
\hline \multicolumn{3}{|l|}{ Age } \\
\hline $18-20$ & 155 & 22.3 \\
\hline $21-23$ & 266 & 38.3 \\
\hline $24-26$ & 169 & 24.3 \\
\hline $27-29$ & 88 & 12.7 \\
\hline $30-32$ & 14 & 2.0 \\
\hline 33-35 & 3 & 0.4 \\
\hline \multicolumn{3}{|l|}{ University } \\
\hline FUTA & 114 & 16.4 \\
\hline EKSU & 117 & 16.8 \\
\hline FUNAAB & 113 & 16.3 \\
\hline OAU & 116 & 16.7 \\
\hline Ul & 114 & 16.4 \\
\hline LASU & 121 & 17.4 \\
\hline \multicolumn{3}{|l|}{ Year of study } \\
\hline First year & 172 & 24.7 \\
\hline Second year & 181 & 26.0 \\
\hline Third year & 168 & 24.2 \\
\hline Fourth year & 122 & 17.6 \\
\hline Fifth year & 28 & 4.0 \\
\hline Postgraduate studies & 24 & 3.5 \\
\hline \multicolumn{3}{|l|}{ Rate of WTS } \\
\hline At least once & 137 & 19.7 \\
\hline Occasional smoker & 267 & 38.4 \\
\hline Frequent smoker & 291 & 41.9 \\
\hline \multicolumn{3}{|l|}{ Length of WTS } \\
\hline $1-5$ years & $\begin{array}{l}673 \\
18 / 26\end{array}$ & 96.8 \\
\hline
\end{tabular}




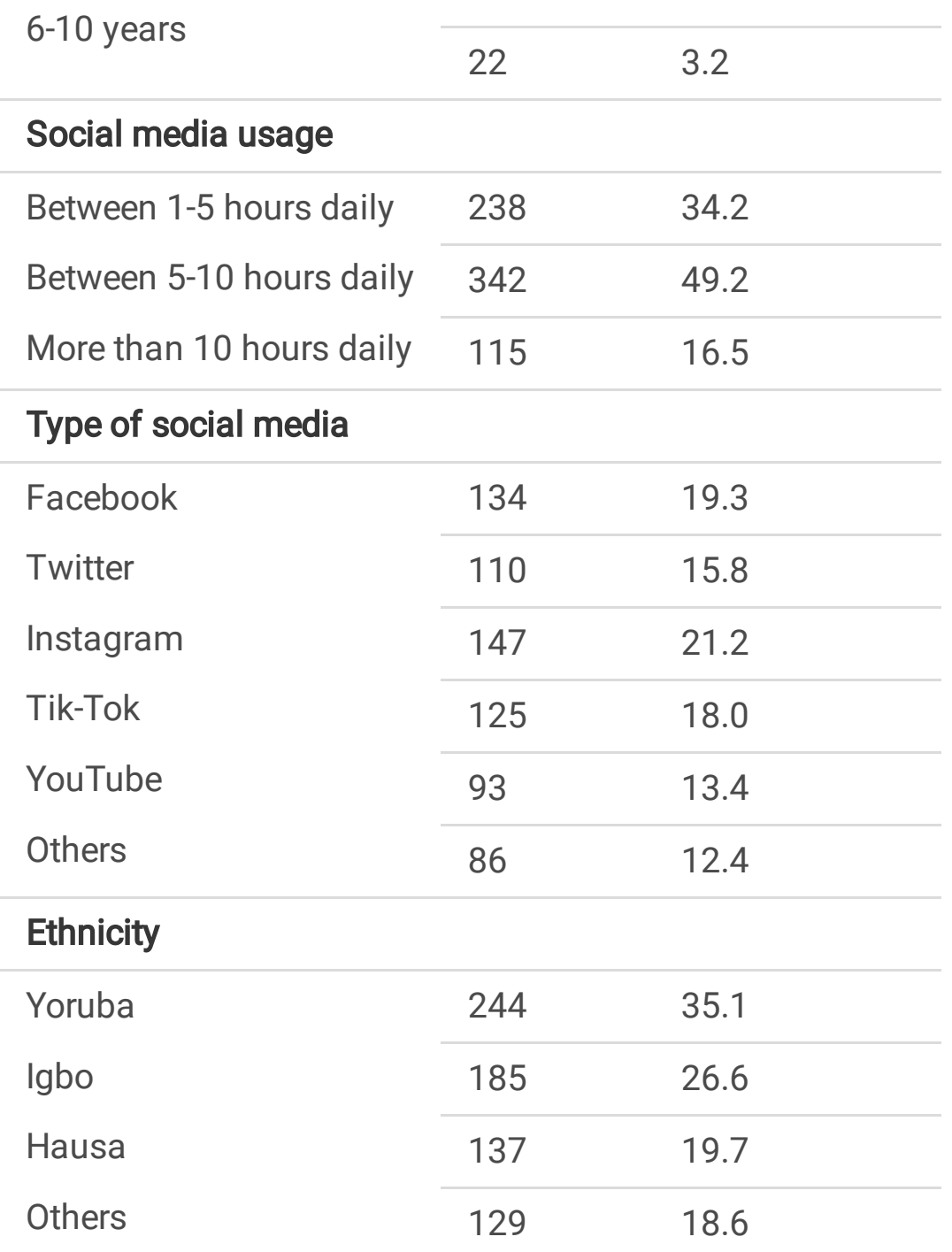

Table 2 Construct reliability, composite reliability, AVE, and VIF values 


\begin{tabular}{|c|c|c|c|c|c|c|c|c|c|}
\hline Constructs & Code & Items & $\begin{array}{l}\text { Outer } \\
\text { loading }\end{array}$ & $\mathrm{CAa}$ & CR & AVE & VIF & $M$ & $S D$ \\
\hline \multirow[t]{4}{*}{$\begin{array}{l}\text { Intention to } \\
\text { smoke } \\
\text { waterpipe } \\
\text { [61] }\end{array}$} & ITSW1 & $\begin{array}{l}\text { I intend to } \\
\text { continue } \\
\text { smoking } \\
\text { waterpipe. }\end{array}$ & 0.828 & 0.890 & 0.924 & 0.753 & 1.897 & 4.13 & 1.78 \\
\hline & ITSW2 & $\begin{array}{l}\text { I will buy } \\
\text { waterpipe if I } \\
\text { happened to } \\
\text { see it in a } \\
\text { store, café, } \\
\text { lounge, or } \\
\text { restaurant. }\end{array}$ & 0.883 & & & & & 3.96 & 1.86 \\
\hline & ITSW3 & $\begin{array}{l}\text { I will actively } \\
\text { seek out } \\
\text { waterpipe in a } \\
\text { store, café, } \\
\text { lounge, or } \\
\text { restaurant to } \\
\text { purchase it. }\end{array}$ & 0.886 & & & & & 3.73 & 1.85 \\
\hline & ITSW4 & $\begin{array}{l}\text { I will patronise } \\
\text { waterpipe as a } \\
\text { tobacco } \\
\text { smoking } \\
\text { product. }\end{array}$ & 0.872 & & & & & 3.96 & 1.87 \\
\hline $\begin{array}{l}\text { Positive } \\
\text { evaluations } \\
\text { of waterpipe }\end{array}$ & PEOW1 & $\begin{array}{l}\text { Waterpipe } \\
\text { smoking is } \\
\text { attractive. }\end{array}$ & 0.878 & 0.943 & 0.952 & 0.688 & 1.959 & 4.72 & 1.87 \\
\hline \multirow[t]{5}{*}{$\begin{array}{l}\text { (Self- } \\
\text { developed) }\end{array}$} & PEOW2 & $\begin{array}{l}\text { Waterpipe } \\
\text { smoking is } \\
\text { fun. }\end{array}$ & 0.859 & & & & & 5.01 & 1.74 \\
\hline & PEOW3 & $\begin{array}{l}\text { Waterpipe } \\
\text { smoking is } \\
\text { relaxing. }\end{array}$ & 0.901 & & & & & 4.83 & 1.83 \\
\hline & PEOW4 & $\begin{array}{l}\text { Waterpipe } \\
\text { smoking is } \\
\text { romantic. }\end{array}$ & 0.819 & & & & & 4.49 & 1.83 \\
\hline & PEOW5 & $\begin{array}{l}\text { Waterpipe } \\
\text { smoking offers } \\
\text { enjoyable } \\
\text { fruity flavours. }\end{array}$ & 0.830 & & & & & 5.13 & 1.73 \\
\hline & PEOW6 & $\begin{array}{l}\text { Waterpipe } \\
\text { smoking is } \\
\text { more } \\
\text { acceptable in } \\
\text { the society } \\
\text { compared to } \\
\text { other methods } \\
\text { of tobacco } \\
\text { smoking. }\end{array}$ & 0.787 & & & & & 4.95 & 1.74 \\
\hline
\end{tabular}




\begin{tabular}{lllll} 
PEOW7 & $\begin{array}{l}\text { Waterpipe } \\
\text { smoking is } \\
\text { less addictive } \\
\text { compared to } \\
\text { other methods } \\
\text { of tobacco } \\
\text { smoking. }\end{array}$ & 0.800 & & \\
PEOW8 & $\begin{array}{l}\text { Waterpipe } \\
\text { smoking is } \\
\text { less harmful } \\
\text { compared to } \\
\text { other methods } \\
\text { of tobacco } \\
\text { smoking. }\end{array}$ & 0.790 & 4.73 & 1.72 \\
PEOW9 & $\begin{array}{l}\text { In general, I } \\
\text { have } \\
\text { favourable } \\
\text { opinion on } \\
\text { waterpipe } \\
\text { smoking. }\end{array}$ & & & \\
\hline
\end{tabular}

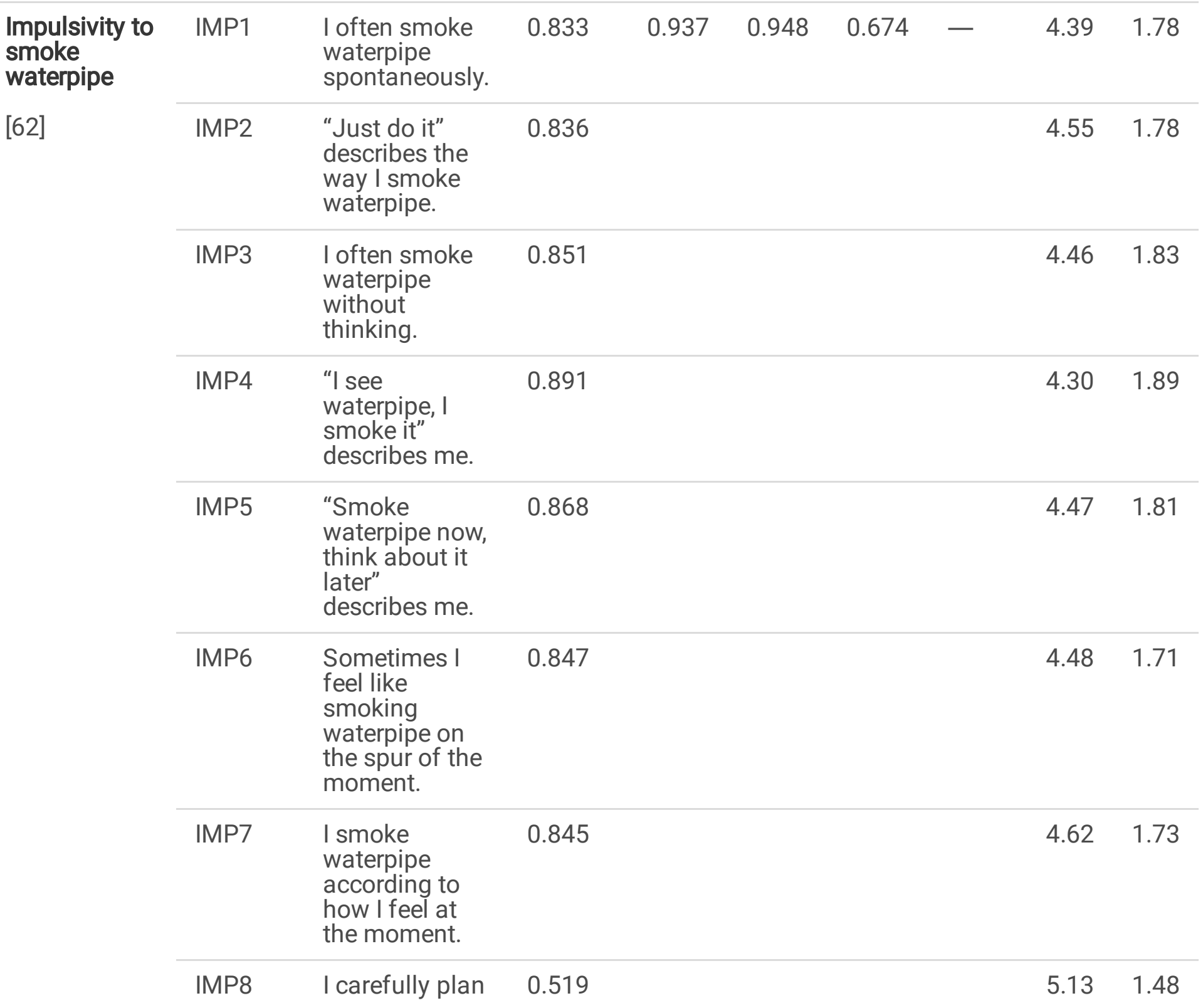




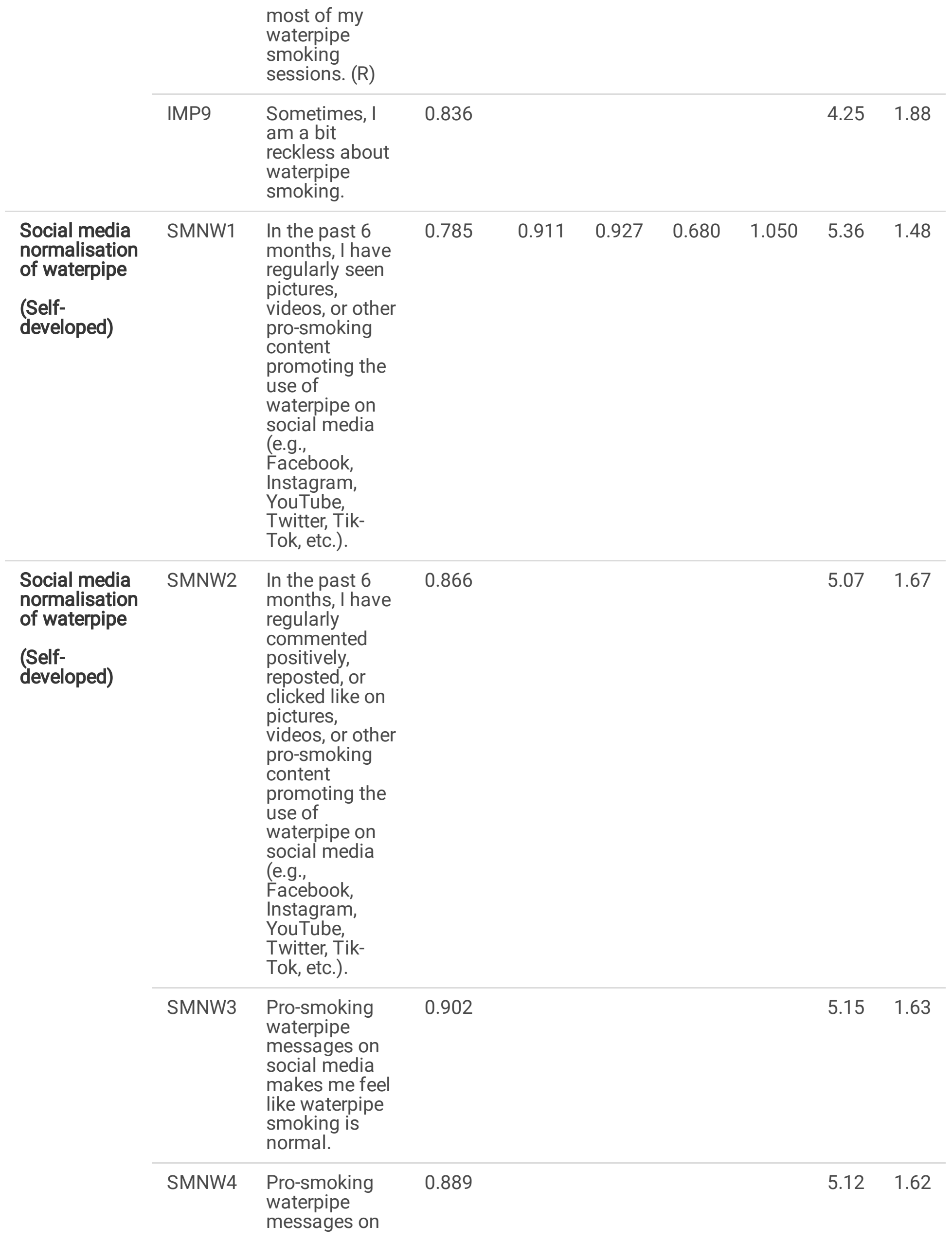




\begin{tabular}{|c|c|c|c|c|}
\hline & $\begin{array}{l}\text { social media } \\
\text { makes me } \\
\text { want to smoke } \\
\text { waterpipe. }\end{array}$ & & & \\
\hline SMNW5 & $\begin{array}{l}\text { Pro-smoking } \\
\text { waterpipe } \\
\text { messages on } \\
\text { social media } \\
\text { can make } \\
\text { people choose } \\
\text { waterpipe as a } \\
\text { tobacco } \\
\text { smoking } \\
\text { alternative. }\end{array}$ & 0.741 & 5.35 & 1.49 \\
\hline SMNW6 & $\begin{array}{l}\text { Pro-smoking } \\
\text { waterpipe } \\
\text { messages on } \\
\text { social media } \\
\text { can make } \\
\text { people want to } \\
\text { smoke } \\
\text { waterpipe. }\end{array}$ & 0.750 & 5.43 & 1.39 \\
\hline
\end{tabular}

${ }^{*} \mathrm{R}$ refers to reverse coded items

Table 3 Discriminant validity: Heterotrait-Monotrait (HTMT)

\begin{tabular}{lllll} 
Variables & IMP & ITSW & PEOW & SMNW \\
\hline IMP & & & \\
\hline ITSW & 0.707 & & & \\
\hline PEOW & 0.634 & 0.743 & & \\
\hline SMNW & 0.211 & 0.113 & 0.202 &
\end{tabular}

Table 4 Structural model results

\begin{tabular}{lllllll} 
Code & Hypotheses & $\boldsymbol{\beta}$ & tvalues & $\mathbf{Q}^{2}$ & $\mathbf{f}^{2}$ & Decision \\
\hline H1 & ITSW -> IMP & 0.442 & $8.414^{\star \star \star}$ & 0.312 & 0.194 & Supported \\
\hline H2 & PEOW->IMP & 0.302 & $5.765^{\star \star \star}$ & - & 0.091 & Supported \\
\hline H3a & ITSW*SMNW->IMP & 0.287 & $3.899 \star *$ & - & 0.136 & Supported \\
\hline H3b & PEOW*SMNW->IMP & 0.186 & $2.923^{\star *}$ & - & 0.112 & Supported
\end{tabular}

*Significant at $\mathrm{P}<0.05$, **at $\mathrm{P}<0.01$, and ***at $\mathrm{P}<0.001$

Figures 


\section{Control variables}

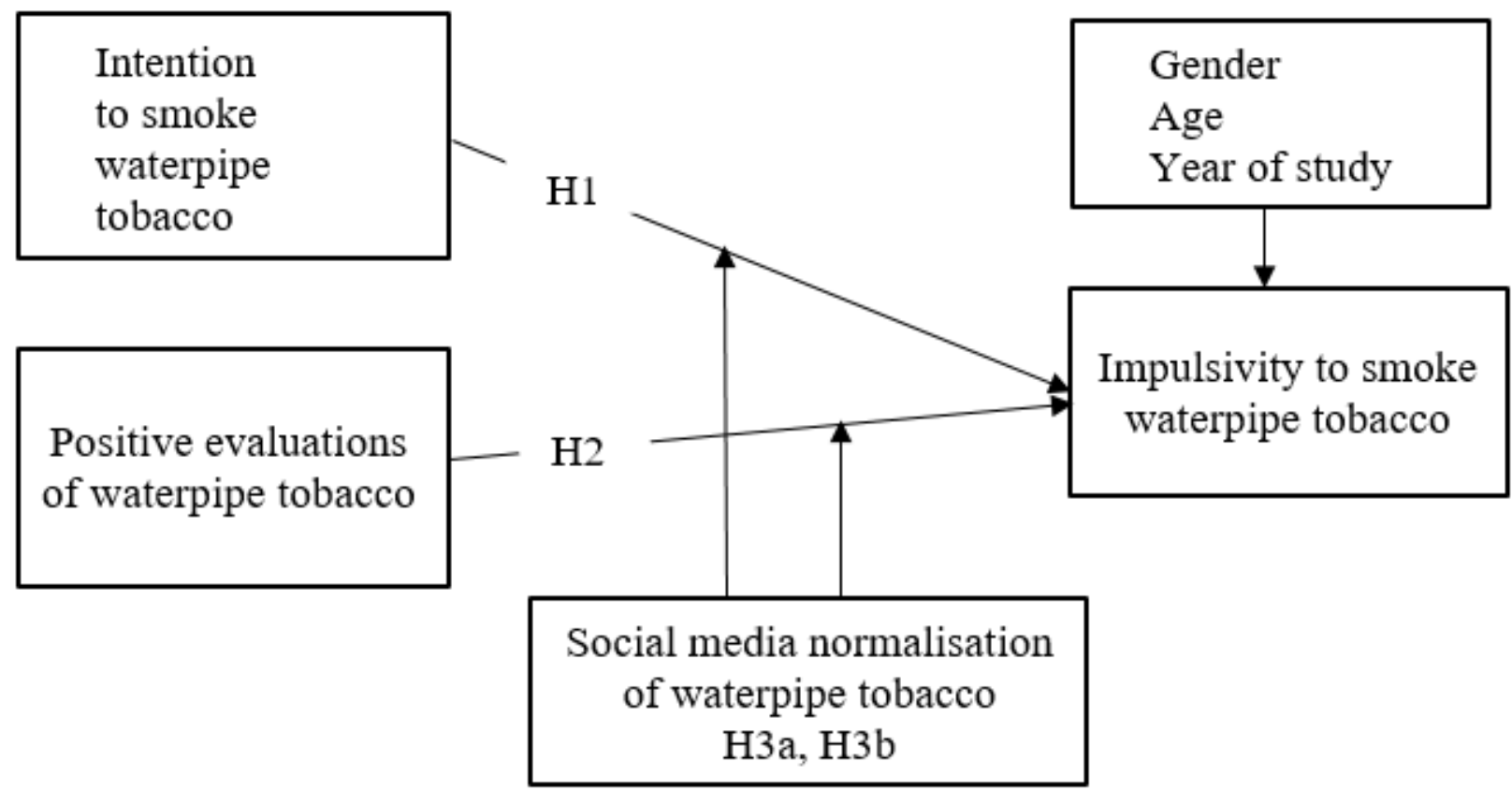

Figure 1

A research model for Nigerian youths' impulsivity to smoke waterpipe tobacco

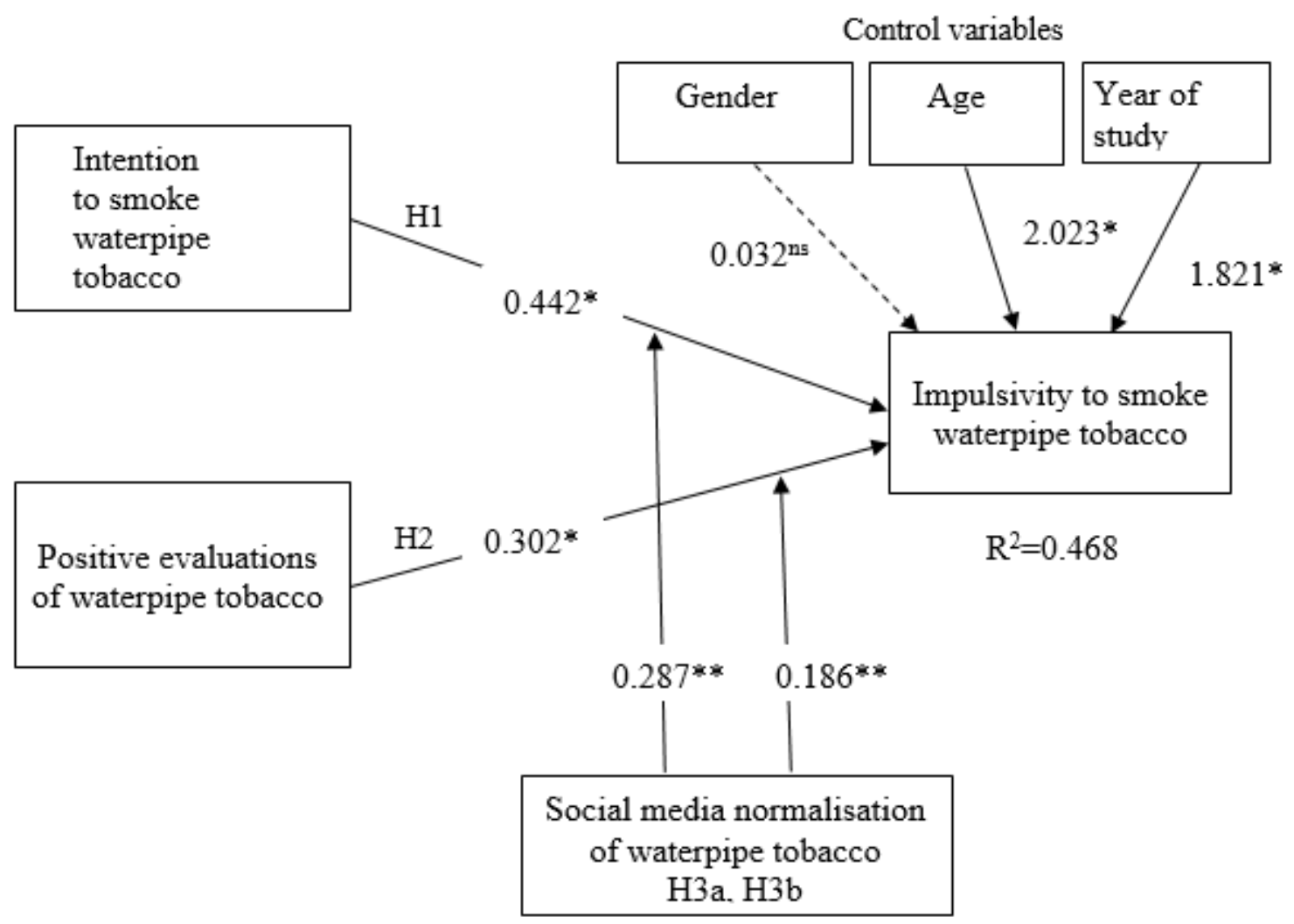

Figure 2 
Structural model for Nigerian youths' impulsivity to smoke waterpipe tobacco. *Significant at $P<0.05$, **at $P<0.01$, ***at $P<0.001$, and NS-not significant

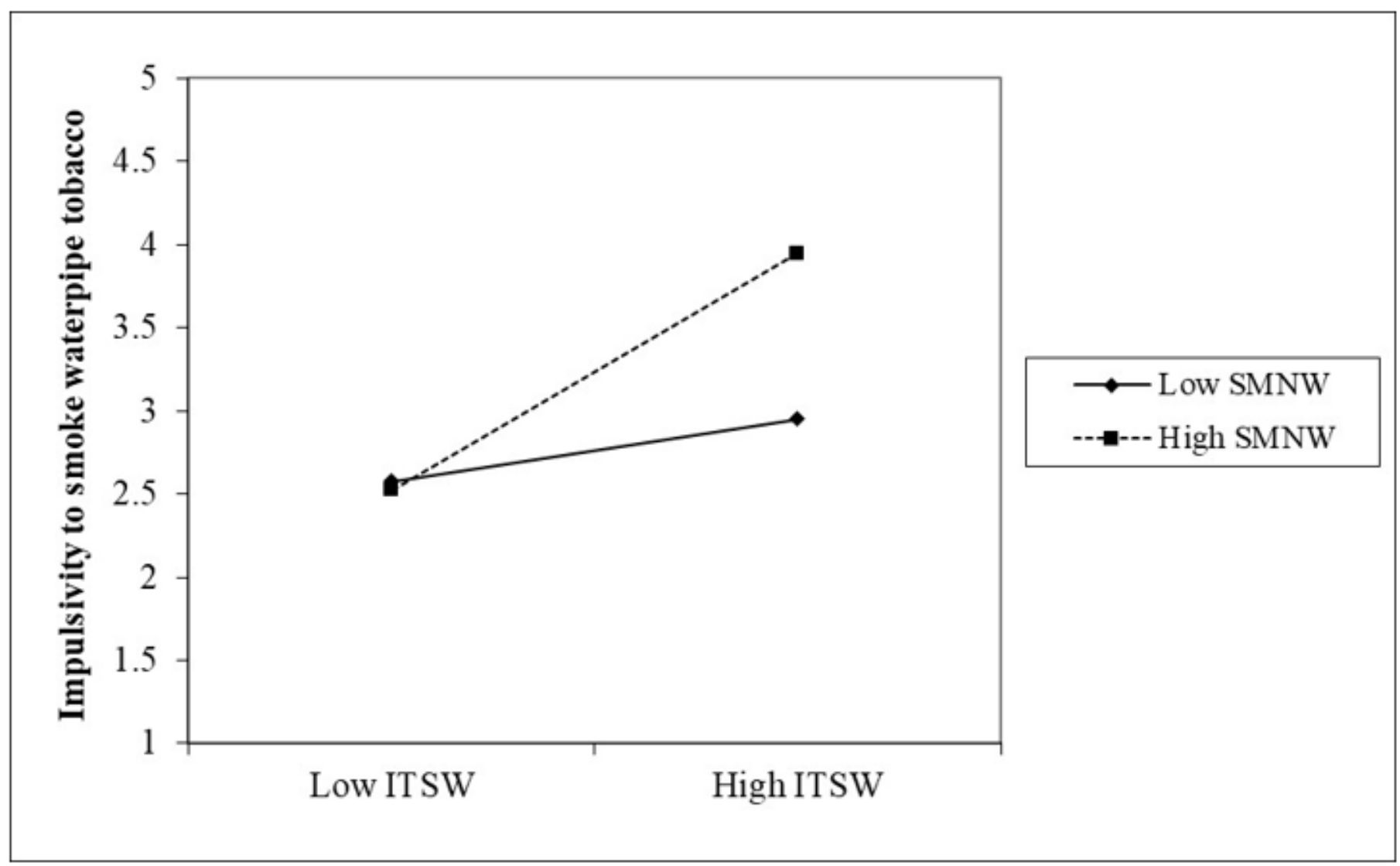

Figure 3

Moderation effect of SMNW on ITSW and impulsivity to smoke waterpipe tobacco 


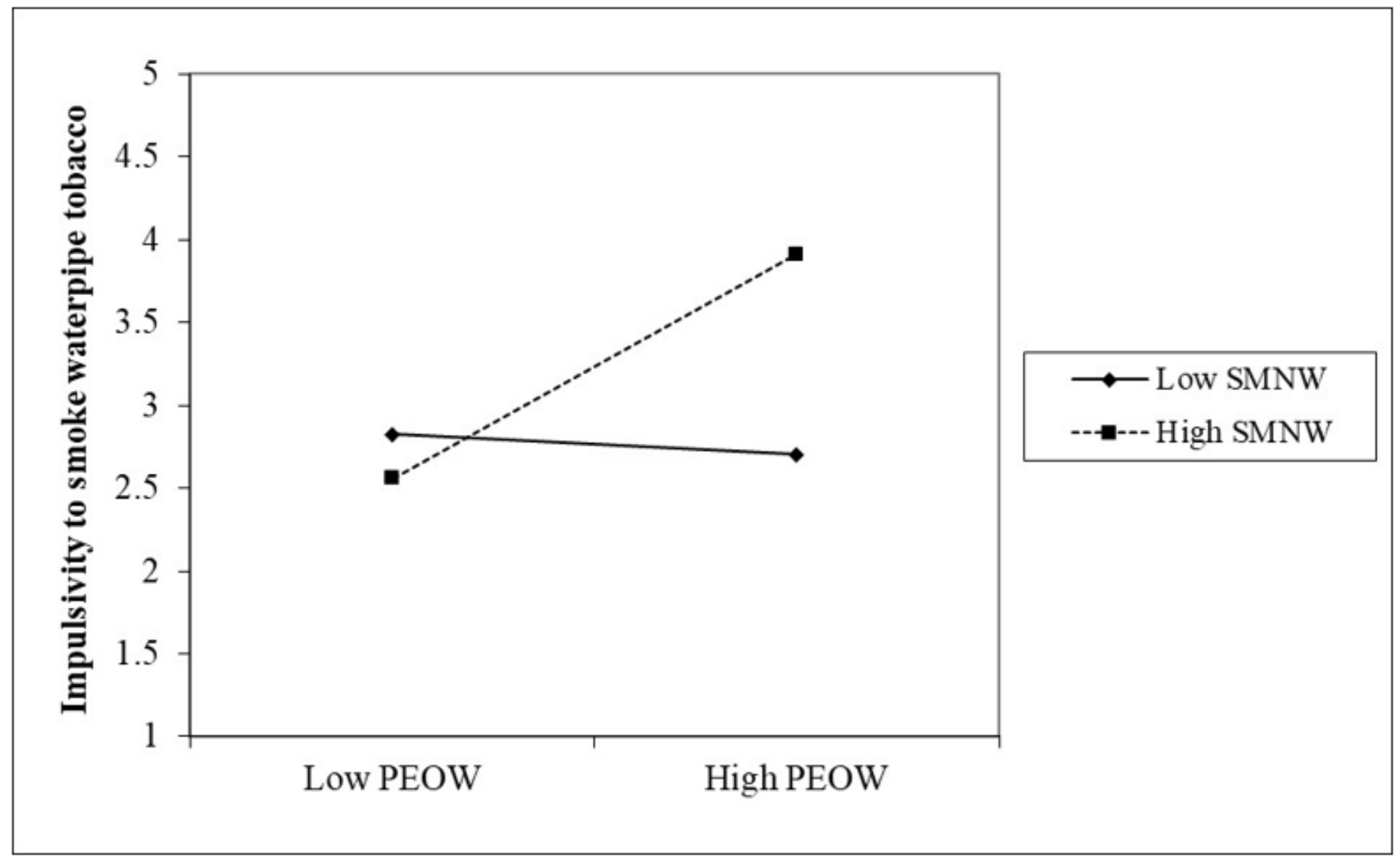

Figure 4

Moderation effect of SMNW on PEOW and impulsivity to smoke waterpipe tobacco 